\title{
Fenntarthatóság, fenntartható ellátási lánc menedzsment
}

\section{Sustainability, sustainable supply chain management}

\author{
A. HORVÁTH ${ }^{1}$, L. KÁROLYI ${ }^{2}$ \\ ${ }^{1}$ Debreceni Egyetem, Ihrig Károly Gazdálkodás- és Szervezéstudományok Doktori Iskola, \\ horv.adrienn@gmail.com \\ ${ }^{2}$ Wekerle Sándor Üzleti Főiskola, Módszertani és Informatikai Tanszék, drkarolyi@gmail.com
}

\begin{abstract}
Absztrakt. A világgazdaság gyors fejlődése, a természeti erőforrások növekvő hiánya és a szennyezés által okozott romlás miatt a környezetvédelem a világ országainak és régióinak alapvető problémája lett. A fenntarthatóság a politikai döntéshozók, az újságírók, a tudósok, az egyetemek és a társadalom körében a világ számos részén és a különböző kutatási területeken közös vita tárgyává. Általánosan elfogadott, hogy a vállalatok fontos szerepet töltenek be a fenntartható fejlődés problémáinak kezelésében is. Ebben a szerepben kulcsfontosságú kihívást jelent a fenntartható fejlódés által okozott gyakran ellentétes nyomások egyensúlyba hozni, azaz a vállalati szintú gazdasági teljesítmény szembenállását a környezeti romlással és a társadalmi zavarokkal. A fenntarthatóság elveinek a vállalatokba való hatékony integrálásához a szervezetek határain túlmutató cselekvésre van szükségük. A fenntarthatóság kérdése egyre eröteljesebben megjelenik a felelős vállalatirányítás eszméi között. Az ellátási lánc menedzsment egyik legfontosabb területe, hogy a vállalatok versenyelönyt szerezzenek a piacon. Ez jelentös hatást gyakorol a természeti környezetre, és egyre nagyobb szükség van a környezeti gondolkodás integrációjára az ellátási lánc menedzsmentjében és folyamataiban, ezért a vállalatok egyre nagyobb figyelmet fordítanak a fenntartható fejlődésre, egyre nagyobb részt vállalnak a vállalati társadalmi felelösségvállalás kezdeményezésekből, a környezetbarát ellátási lánc elérésért. Az elmúlt évtizedekben kidolgozták a fenntartható és a zöld ellátási lánc menedzsment gyakorlatokat, ezzel próbálva integrálni a környezetvédelmi szempontokat a szervezetekbe, a termelési és fogyasztási folyamatok környezetére gyakorolt, nem kívánt negatív következmények csökkentésével. Jelen cikkben a szakirodalmakat alapul véve fóként leíró szekunder kutatás során vizsgáltam a fenntarthatóság és a fenntartható ellátási lánc menedzsment kérdéskörét.
\end{abstract}

Abstract. With the rapid development of the world economy, the growing scarcity of natural resources and the degradation caused by pollution, environmental protection has become a major concern for countries and regions of the world. Sustainability is a common subject in many parts of the world and the various research areas among policy makers, journalists, scientists, universities and social debate. It is generally accepted, that companies also play an important role in addressing the challenges of sustainable development. In this role, making a key challenge to balance often conflicting pressures caused by sustainable development, that is, the level of corporate economic performance against environmental deterioration and social disruption. Effective integration of sustainability principles into companies requires action beyond the borders of organizations. The issue of sustainability is becoming more and more prominent in corporate governance. One of the most important area of supply chain management is for companies to gain a competitive edge in the market. This has a significant impact on the natural environment, and there is a growing need to integrate environmental thinking in supply chain management and processes, which is why companies are increasingly focusing on sustainable development, taking on more CSR 
initiatives and achieving a greener supply chain. Sustainable and green supply chain management practices have been developed over the past decades, trying to integrate environmental considerations into organizations by reducing unwanted negative consequences for the environment of production and consumption processes. In this article, I have examined the issues of sustainability and sustainable supply chain management, mainly based on descriptive secondary literature.

\section{Bevezetés}

A fenntarthatóság a folyamatos létezés képessége. A 21. században ez általában a bioszféra és az emberi civilizáció együttélési képességére utal. Az alapvető emberi igények kielégítése a Föld életét támogató rendszerek megőrzése mellett a fenntarthatóság felé történő gyorsított átmenet megkövetelését igényli. Felmerül egy új fenntarthatósági tudományterület, amelynek célja a természet és a társadalom közötti kölcsönhatások alapvető jellegének megértése, s e kölcsönhatások ösztönzése. A fenntarthatóság kérdése egyre erőteljesebben megjelenik a felelős vállalatirányítás eszméi között. Többek között a klímaváltozás, a környezeti problémák észrevehető hatásai, a fosszilis energiahordozói készletek fogyatkozása, és még számos más tényezőkre a vállalatok egy része nagyobb hangsúlyt fektet, és alakít ki fenntarthatósági, környezetvédelmi vagy társadalmifelelősségvállalási politikát. A fenntarthatóság a politikai döntéshozók, a tudósok, az egyetemek és a társadalom körében a világ számos részén és a különböző kutatási területeken közös vita tárgyává vált. A fenntarthatóság egyre növekvő befolyása az ellátásilánc menedzsmentjében és a múködési gyakorlatokban is azzal magyarázható, hogy az erős gazdasági teljesítmény iránti megnövekedett igények mellett a szervezetek és főbb érdekeltek felelősek a környezeti és társadalmi teljesítményért. A mai irodalom a fenntarthatóság alatt három különböző, de egymással összefüggő témát ért, mint a fenntartható fejlődés, a környezetvédelem és a társadalmi felelősségvállalás területei. A fenntarthatóság fogalmának többértelműsége olyan probléma, amellyel a kutatók is gyakran szembesülnek. A nem működőképes, változatos és néha ellentmondásos meghatározások megléte nehézséget jelent a fenntarthatóság megfelelő koncepciójának megválasztásában. Még a legtöbb kutatás, amelynek címe tartalmazza a fenntarthatóság fogalmát, sem határozza meg pontosan mit is értünk alatta. Ez arra készteti a kutatókat, és a vállalati szféra szakembereit is, hogy kerüljék a fenntarthatóság meghatározását. Jelen cikkben szakirodalmakat alapul véve főként leíró, szekunder kutatás során vizsgáltam a fenntarthatóság, és a fenntartható ellátási lánc menedzsment fóbb alapértelmezéseit. „A szakirodalmi áttekintés szisztematikus, egyértelmű és reprodukálható terv a meglévő feljegyzett dokumentumok azonosítására, értékelésére és értelmezésére [6]”.

\section{A fenntarthatóság és a fenntartható ellátási lánc menedzsment alapértelmezései}

\subsection{Fenntarthatóság}

Az Egyesült Nemzetek Szervezete (továbbiakban: ENSZ) 1987-es Közös Jövőnk vagy más néven BRUNDTLAND (1987) jelentés megfogalmazása szerint: „A fenntartható fejlődés, olyan fejlődés, amely 
kielégíti a jelen generációk szükségleteit anélkül, hogy veszélyeztetné a jövő generációk igényeinek kielégítését”. Egy másik megfogalmazásban: „A fenntartható fejlődés a folyamatos szociális jólét elérése anélkül, hogy az ökológiai eltartóképességet meghaladó módon növekednénk. A növekedés azt jelenti, hogy nagyobbak leszünk, a fejlődés pedig azt, hogy jobbak" [4]. Ez a meghatározás egyértelművé teszi, hogy a fenntartható fejlődés célja a társadalom fenntartása, a gazdaság a jólét megvalósításának az eszköze, a környezet pedig feltétele (egyszerre lehetősége és korlátja) a fejlődésnek. A gazdasági életben a fenntartható fejlődés általában nincs ellene a növekedésnek. A fejlődő világ sohasem fogadna el egy olyan koncepciót, amely megtiltaná számára a gazdasági növekedést. Fenntarthatónak azt a fejlődési módot nevezzük, amely a jelen szükségleteit úgy elégíti ki, hogy egyúttal nem veszélyezteti a jövő generációk szükségleteinek kielégítését. „A fogalom a fenntartható gazdasági, ökológiai és társadalmi fejlődést egységben értelmezi” [25]. „A fenntartható fejlődés nem igényli a szükségleteink korlátozását, csak arra biztat, hogy igyekezzünk azokat kevesebb anyag-, és energia felhasználásával kielégíteni” [15]. A fogalom tágabb értelmezése szerint jelenti a fenntartható gazdasági, ökológiai és társadalmi fejlődést is, de szokás használni szűkebb jelentésben is, a környezeti értelemben vett (értsd: időben folyamatos erőforrás-használat és környezeti menedzsment) fenntartható fejlődésre korlátozva a fogalom tartalmát [14]. [10] szerint a gazdasági növekedés, a környezet minősége és a szociális egyenlőség lenne az a bizonyos három tartópillére a fenntarthatóságnak [IN:9] A fenntartható fejlődést a Brundtland-bizottság egy háromlábú székként képzelte el, amelynek a három lábát a környezet-, a gazdaság-, és a szociálpolitika képezi [17]. Ez a három tartó pillér kölcsönösen feltételezi egymást, ezért a fenntarthatósági politikákban is kiegyensúlyozottan szükséges megjeleníti őket, a fenntarthatóság a három pillér meglétével működik megfelelően. Ez azon az elgondoláson alapul, hogy a vállalkozásoknak a környezetvédelmi, társadalmi és gazdasági célokat optimalizáló módon kell működniük: ezt gyakran nevezik a hármas optimalizálás/hármas célrendszernek, azaz a Triple Bottom Line (továbbiakban: TBL) elvének nevezik (1. ábra).

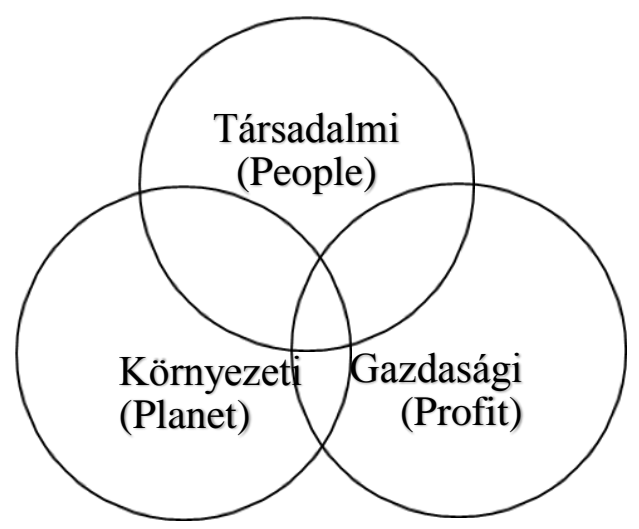

1. ábra: Hármas célrendszer elve

A TBL fogalom vagy 3P (people (emberek), plane (bolygó), profit (nyereség) bevezetése ELKINGTON nevéhez fűződik. A 3 találkozásában érhető el a fenntartható fejlődés. Míg a társadalmi-környezeti találkozásakor beszélhetünk társadalmi-környezeti fejlődésről (socio-environmental), a társadalmigazdasági (socio-economic) és öko-gazdasági (eco-economic) fejlődés érhető el a környezeti és 
gazdasági pillérek találkozáskor. A TBL azt javasolja, hogy a vállalatoknak a környezetminőség, a társadalmi igazságosság és a gazdasági jólét optimalizálásával minimalizálniuk kell a tevékenységeikből eredő károkat, valamint támogatniuk kell a teljes „rendszer” növekedést. Azaz a fenntartható vállalkozás hozzájárul ahhoz a fenntartható fejlődés, gazdasági, társadalmi és környezeti előnyök egyidejű biztosításával [5]. Vagyis egy fenntartható vállalat gazdaságilag életképes, a környezetre nem terhelő és társadalmilag felelős [2]. A „Triple Bottom Line” paradigma mögött, tulajdonképpen az a gondolat húzódik meg, hogy a vállalat végső sikere vagy nem csak a hagyományos pénzügyi teljesítményén múlik, hanem a társadalmi/etikai és környezeti teljesítménye is hatással van rá. [26] szerint a fenntartható vállalat azt jelenti, hogy a vállalkozói szellem pozitív hatásait és kreatív lehetőségeit nagyobb mértékben kihasználjuk, mint valaha, a társadalmunk fenntartható fejlődése érdekében. A TBL keretet biztosít az üzleti teljesítmény és a szervezet sikerének mérésére a gazdasági, társadalmi és környezeti vonalak felhasználásával [8]. A kifejezést a fenntarthatóság gyakorlati keretének is nevezik [22]. A vállalatok felé irányított TBL következetes és kiegyensúlyozott figyelmet fordít a szervezetek által nyújtott gazdasági, társadalmi és környezeti értékre.

\subsection{Fenntartható ellátási lánc menedzsment}

A fenntartható fejlődés koncepciójának megvalósulását globális (ENSZ), regionális (EU) és nemzeti szinteken hathatós ösztönzés övezi. Emellett mára kiemelt hangsúly került a mikrogazdasági szereplők szintjére, mivel konszenzus alakult ki abban, hogy a vállalatok tevékenysége alapvetően befolyásolja a koncepció megvalósulását [21]. A vállalati menedzsmentben a környezeti tényezők fontossága a vállalati működésben, a fenntarthatóság és a zöld szempontok ma már általánosan elfogadott, jelentőségét sokan hangsúlyozzák. A fenntarthatóság kérdése egyre erőteljesebben megjelenik a felelős vállalatirányítás eszméi között [13]. A 21. századi támasztotta kihívásokra megoldást jelentett az úgynevezett Sustainable Supply Chain Management (továbbiakban: SSCM), vagyis a fenntartható ellátási lánc menedzsment. A környezeti szempontokat is figyelembe vevő ellátási lánc menedzsment a szakirodalomban többféle elnevezéssel is megjelenik, ezek közül is a leggyakrabban a fenntartható ellátási lánc menedzsment, a környezettudatos ellátási lánc menedzsment és a zöld ellátási lánc menedzsment fogalmakkal találkozhatunk [18]. A fenntartható ellátási lánc menedzsment kulcsfontosságú megközelítésként jelent meg a környezetvédelmi szempontból fenntarthatóvá váló vállalkozások számára. Az SSCM a jövedelmezőséget a környezeti és társadalmi szempontokat veszi figyelembe. Alapját tulajdonképpen a környezetvédelem és a gazdaságosság párosa jelenti, vagyis egy mondatban azt mondhatjuk, hogy a „profit realizálásával megfelelni a környezetvédelmi elvárásoknak [16]”. A fenntartható fejlődés TBL koncepciójára épül a fenntartható ellátási lánc is. A modell értelmezésében fontos, hogy minden dimenziót egyidejûleg és azonos arányban, s nem elkülönülten, hanem egymásba integráltan értelmezzünk. A három terület együttes eredményes alkalmazásához szükséges azonban a stratégiai szemléletmód, valamint egy jól strukturált vállalat és egy hálózatspecifikus üzleti modell kialakítása. Míg a hagyományos ellátási lánc menedzsmentben a tervezés, irányítás, vezetés, valamint az ezek által koordinált folyamatok kerültek előtérbe. Addig ezzel szemben a SSCM a fenntarthatóság biztosítására fókuszál és a három dimenziót egy struktúrában alakítja ki és harmonizálja a fenntartható fejlődés biztosítása érdekében. Továbbá különbözik még abban, hogy szélesebb szemléletmóddal tekint az ellátási lánc egészére. Tulajdonképpen az ellátási 
lánc menedzsment teljes körű megvalósítása csak stratégiai szinten értelmezhető, így egy megfelelő üzleti stratégia és modell kialakítása szükséges [3, 7, 16, 19].

A fenntartható ellátásilánc menedzsment feladata a környezetre tett káros hatások minimalizálása, a társadalmi jólét hozzájárulásának és profit maximalizálása mellett. Ez azonban ellentmondást mutat, hiszen a profit maximalizálás a folyamatok költség csökkentésével történhet, addig a káros környezeti hatások megóvása és társadalmi jólét biztosítása működési költség növeléssel járhat. Az ellátási láncokban elérhető fenntarthatóságot több szereplő döntéseivel kell összehangolni, a környezeti és a társadalmi hatásokat pedig a többszereplős ellátási lánc szintjén érdemes mérni [11, 12]. [24] az alábbiakban fogalmazták meg a fenntartható ellátásilánc menedzsmentet: az anyag-, információ- és tőkeáramlás menedzselése, valamint a vállalatok közötti együttműködés az ellátási lánc mentén, figyelembe véve a fenntartható fejlődés mindhárom dimenzióját, azaz a gazdasági, környezeti és társadalmi szempontokat, amelyek az ügyfél és az érdekelt felek elvárásaiból származnak. A hálózati struktúrában működő vállalatok társadalmi felelősségvállalásának minőségére, a hálózatot alkotó többi szervezeti egység felelősségvállalását is befolyásolja. Ebből következik, hogy egyes szervezet abban az esetben képes felelős tevékenységét biztosítani, amennyiben az ellátási lánc többi szereplője is hasonlóan cselekszik [16]. Fontos, hogy a vállalat ellátási lánca társadalmilag felelős és etikus legyen. A működési teljesítmény egyik dimenziója, amelyet be kell építeni a kockázatkezelés és a jó hírnév javítása. Az SSCM gyakorlatának jelentős hatása van a szervezetek környezeti és működési teljesítményére.

\section{Összegzés}

A világgazdaság gyors fejlődése, a természeti erőforrások növekvő hiánya és a szennyezés által okozott romlás miatt a környezetvédelem a világ országainak és régióinak alapvető problémája lett. A fenntarthatóság szó hallatán hajlamosak vagyunk a megújuló energiaforrásokra, a szén-dioxidkibocsátás csökkentésére, a környezet védelmére és a bolygónk érzékeny ökoszisztémáinak egyensúlyban tartására gondolni, és általánosan elfogadottá vált, hogy a vállalatok fontos szerepet töltenek be ezen problémák kezelésében is. A fenntartható fejlődés fogalmának értelmezése nem egységes, rendkívüli módon széttartó, ezért minden fenntartható fejlődéssel kapcsolatos tevékenység kezdőlépése kell legyen, hogy az aktuális fogalomhasználatnál az értelmezés módjáról döntsünk [1]. Általában a fenntarthatóság kifejezés használatát feltáró állítások rendszerének vizsgálatakor négy felhasználást és azok jelentését azonosították: (1) a fenntarthatóság mint az emberi cselekvéshez vezető társadalmi-ökológiai kritériumok halmaza, (2) a fenntarthatóság mint az emberiség jövőképe, amelyet egy adott referenciarendszer társadalmi és ökológiai céljainak konvergenciája révén valósítanak meg, (3) fenntarthatóság mint tárgy, dolog vagy jelenség, amely bizonyos társadalmiökológiai rendszerekben előfordul, és (4) a fenntarthatóság, mint olyan megközelítés, amely magában foglalja a társadalmi és ökológiai változók beépítését egy tevékenység, folyamat vagy emberi termék tanulmányozásába [23]. A fenntarthatóság elvinek a vállalatokba való hatékony integrálásához a szervezetek határain túlmutató cselekvésre van szükségük, a fenntarthatósági stratégia nehezen számszerűsíthető előnyöket eredményezhet. A fenntartható vállalati növekedés a környezettudatos vállalati magatartás, a hosszú távú működés feltétele. Meghatározó versenyelőnyt jelenthet a 
vállalatról alkotott külső megítélés, azaz a jó vállalati imázs, amely nagy részben a vállalat érintettjei (vevők, szállítók, kormányzat) befolyásolnak. Lehetőséget ad a vállalatok számára a profit biztosításra, az igények (imázs, hírnév, társadalmi megítélés) javítására, a meglévő vevői igények jobb kiszolgálására, ezen belül is a hatóságokkal való jobb kapcsolat kiépítésére [20].

\section{Hivatkozások}

[1] G. BARTUS (2013): A fenntartható fejlődés fogalom értelmezésének hatása az indikátorok kiválasztására. Statisztikai Szemle. Vol. 91. No. 8-9. pp. 842-869.

[2] SZ. BÁRTH-FEHÉR (2012): Fenntarthatóság a hazai vállalati gyakorlatban-A „Versenyben a világgal" kutatási program 2009. évi kérdőives felmérés eredményeinek vizsgálata. Vezetéstudomány. Vol. 53. No. 10. pp. 44-55.

[3] M. Czikkely-J. Oláh-Z. Lakner-Cs. Fogarassy-J. Popp (2018): Waste water treatment with adsorptions by mushroom compost: The circular economic valuation. International Journal of Engineering Business Management. Vol. 10. No. pp. 1-12.

[4] DALY, H. (1990) Toward some operational principles for sustainable development. Ecological Economics, Vol. 2. No. 1. pp. 1-6.

[5] ELKINGTON, J. (1998): Partnerships fromcannibals with forks: The triple bottom line of 21stcentury business. Environmental Quality Management. Vol. 8. No. 1. pp. 37-51.

[6] FINK, A. (1998): Conducting Research Literature Reviews: From Paper to the Internet, Sage, Thousand Oaks.

[7] Cs. Fogarassy-É. Neubauer-H. Mansur-A. Tangl-J. Oláh-J. Popp (2018): The main transition management issues and the effects of environmental accounting on financial performance - with focus on cement industry. Administratie si Management Public, Vol. 31. pp. 52-66.

[8] GOEL, P. (2010). Triple bottom line reporting: An analytical approach for corporate sustainability. Journal of Finance, Accounting, and Management. Vol. 1. No. 1. pp. 27-42.

[9] I. GYULAI (2013): Fenntartható fejlödés és fenntartható növekedés. Statisztikai Szemle. Vol.91. No. 8-9. pp. 797-822.

[10] HASNA, A. M. (2007): Contemporary Society, Technology and Sustainability. The International Journal of Technology, Knowledge and Society. Vol. 5. No. 1. pp. 13-20. In Gyula Iván (2013): Fenntartható fejlődés és fenntartható növekedés. Statisztikai Szemle. Vol. 91. No. 8-9. pp. 797822.

[11] HASNA, M. (2013): Sustainable Supply Chain Management Practices and Operational Performance. American Journal of Industrial and Business Management. Vol. 3. pp. 42-48.

[12] HASSINI, E.-SURTI, C.-SEARCY, C. (2012): A literature review and a case study of sustainable supply chains with a focus on metrics. International Journal of Production Economics. Vol. 140. No.1.pp. 69-82.

[13] A. HORVÁTH (2017): Fenntarthatóság mérési lehetőségei. LOGISZTIKAI TRENDEK ÉS LEGJOBB GYAKORLATOK. 3: (1) pp. 17-20. DOI: 10.21405/logtrend.2016.2.2.17.

[14] S. KEREKES-J. SZLÁVIK (2001): A környezeti menedzsment közgazdasági eszközei. KJK-KERSZÖV Jogi és Üzleti Kiadó Kft., Budapest, 295. p. (ISBN: 963-224-616-0)

[15] S. KEREKES (2007): A környezetgazdaságtan alapjai. Aula Kiadó Kft., Budapest, 238. p. 
[16] T. KOZMA-M. PÓNUSZ (2016): Ellátásilánc-menedzsment elmélete és gyakorlata-alapok. Alapösszefüggések a hálózati versenyelőnyök és értékláncok mentén. Károly Róbert Kutató-Oktató Közhasznú Nonprofit Kft., Gödöllő, 181 p.

[17] K. MEDVÉNÉ DR. SZABAD (2010): A fejlődés gazdaságtana. Budapesti Gazdasági Főiskola, Budapest http://tinyurl.hu/vGwJ/ Letöltés dátuma: 2017.10.26.

[18] G. M. MISKOLCZINÉ (2017): Zöld ellátási lánc menedzsment átfogó vizsgálata a hazai közúti gépjármúiparban Doktori (Ph.D.) értekezés. Szent István Egyetem Gazdálkodás- és Szervezéstudományok Doktori Iskola, Gödöllő, 153 p.

[19] J. Popp-J. Oláh-A. Kiss-Á. Temesi-Cs. Fogarassy-Z. Lakner (2019): The socio-economic force field of the creation of short food supply chains in Europe. Journal of Food and Nutrition Research, Vol. 58. No.1. pp. 31-41.

[20] PORTER, M. E.-KRAMER, M. R. (2006): Strategy and Society: The Link Between Competitive Advantage and Corporate Social Responsibility. Harward Business Review. Vol. 89. No. 12. pp. 7892.

[21] B. RANSBURG-M.VÁGÁSI (2011): A fenntartható fejlődés vállalati integrációja és kommunikációja. A hazai nagyvállalati gyakorlat vizsgálata. Vezetéstudomány, Vol. 42. No. 10. pp. 2-13.

[22] ROGERS, K.-HUDSON, B. (2011): The triple bottom line: The synergies of transformative perceptions and practices of sustainability. OD Practitioner. Vol. 4. No. 43. pp. 3-9.

[23] SALAS-ZAPATA, W. A.-ORTIZ-MUÑOZ, S. M. (2019): Analysis of meanings of the concept of sustainability. Sustainable Development. Vol. 27. No. 1. pp. 153-161.

[24] SEURING, S.-MÜLLER, M. (2008): From a literature review to a conceptual framework for sustainable supply chain management. Journal of Cleaner Production. Vol. 16. No. 15. pp. 16991710.

[25] J. SZLÁVIK (2005): Fenntartható környezet-és erőforrás-gazdálkodás. KJK-KERSZÖV Jogi és Üzleti Kiadó Kft., Budapest, 317 p.

[26] WEIDINGER, C.-FISCHLER, F.-SCHMIDPTER, R. (2014): Sustainable Entrepreneurship-Business Sucess through Sustainability. Springer Kiadó, Heidelberg, 314 p. 